\title{
Intestinal Dendritic Cells in Health and Gut Inflammation
}

\author{
Andrew J. Stagg* \\ Centre for Immunobiology, Blizard Institute, Barts and The London School of Medicine and Dentistry, Queen Mary University \\ of London, London, United Kingdom
}

Dendritic cells (DCs) mediate tolerance to food antigens, limit reactivity to the gut microbiota and are required for optimal response to intestinal pathogens. Intestinal DCs are heterogeneous but collectively generate both regulatory and effector $T$ cell responses. The balance of outcomes is determined by the activity of functionally distinct DC subsets and their modulation by environmental cues. DCs constantly sample luminal content to monitor for pathogens; the significance of the various pathways by which this occurs is incompletely understood. Intestinal DC have distinctive properties shaped by local host, dietary and microbial signals. These properties include the ability to produce all-trans retinoic acid (RA) and imprint gut tropism on T cells they activate. In the steady-state, subsets of intestinal DC are potent generators of inducible Treg, aided by their ability to activate TGF $\beta$ and produce RA. However, responses induced by steady-state intestinal DCs are not exclusively regulatory in nature; effector T cells with specificity for commensal

OPEN ACCESS

Edited by:

Marcela A. Hermoso,

Universidad de Chile, Chile

Reviewed by:

Eduardo J. Villablanca, Karolinska Institutet (KI), Sweden

Fernando G. Chirdo, National University of La Plata,

Argentina

*Correspondence:

Andrew J. Stagg

a.stagg@qmul.ac.uk

Specialty section:

This article was submitted to

Mucosal Immunity,

a section of the journal

Frontiers in Immunology

Received: 13 July 2018 Accepted: 23 November 2018 Published: 06 December 2018

Citation:

Stagg AJ (2018) Intestinal Dendritic Cells in Health and Gut Inflammation.

Front. Immunol. 9:2883.

doi: 10.3389/fimmu.2018.02883 bacterial can be found in the healthy mucosa and these can be locally controlled to prevent inflammation. The ability of intestinal DCs to enhance effector responses in infection or sustain inflammation in disease is likely to involve both modulation of the local DC population and recruitment of additional populations. Immune pathways in the pathogenesis of inflammatory bowel disease can be mapped to DCs and in inflamed intestinal tissue, DCs show increased expression of microbial recognition machinery, activation, and production of key immunological mediators. Intestinal DCs may be targeted for disease therapy or to improve vaccine responses.

Keywords: Dendritic cells, intestinal inflammation, antigen sampling, lymphocyte homing, inflammatory bowel disease

\section{INTRODUCTION}

Dendritic cells (DCs) are bone marrow-derived antigen presenting cells which comprise two major subsets: conventional (or classical) DCs (cDCs) and plasmacytoid DC (pDC). They are developmentally distinct from both tissue resident macrophages and monocyte-derived populations (1) but share many phenotypic markers with these populations. Historically this has led to confusion and apparently conflicting data in analyses of DCs in the intestine. However, recent development of better strategies for DC identification, together with improved cell isolation techniques that help maintain DCs in their native state $(2,3)$, and genetic tools that enable specific deletion of DC populations in vivo, have enabled a clearer picture of the role of DCs in the intestine to emerge.

cDCs play critical roles in immune regulation in the intestine and are the focus of this review. The reader is referred to a recent review article (4) for more information on the role of pDC in the 
intestine. cDCs are required for induction of oral tolerance (5) and the generation of regulatory $\mathrm{T}$ cells (Treg) recognizing soluble antigens (5) and commensal microbes (6, 7). They are also required for optimal protective immune responses against diverse pathogens (8-12). The balance of regulatory and effector responses is influenced by the contribution of functionally distinct $\mathrm{CDC}$ subsets as well as their modulation by environmental cues.

\section{INTESTINAL DENDRITIC CELLS IN THE STEADY-STATE}

\section{Heterogeneity of Intestinal DCs}

Intestinal $\mathrm{cDCs}$ are found within organized lymphoid tissue, including Peyer's patches (PP) (13) and draining lymph nodes, as well as in the lamina propria (LP) of small intestine (SI) and colon (14-16). As in other tissues, LP cDCs comprise cDC1 and CDC2 which can be defined in mice and humans by expression of X-C motif chemokine receptor 1 (XCR1) or signal regulatory protein $\alpha$ (SIRP $\alpha / C D 172 a)$, respectively, $(1,17)$.

Additional cell surface markers are used in particular species to define intestinal $\mathrm{cDC}$ subsets further. In mice, $\mathrm{cDC} 1$ are CD103+CD11b-, whereas cDC2 comprise CD103-CD11b+ cells and a gut-specific CD103+CD11b+ population (18) (Figure 1). The two CD11b+ populations are closely related; $\mathrm{CD} 103-\mathrm{CD} 11 \mathrm{~b}+\mathrm{cDC}$ give rise to $\mathrm{CD} 103+\mathrm{CD} 11 \mathrm{~b}+$ cells under the influence of TGF $\beta$ (23). There are more CD103+CD11b+ in the SI than in the colon (24). Equivalent $\mathrm{CDC}$ populations are present in the human intestine (25) and are often identified based on expression of CD103 in conjunction with SIRP $\alpha$ rather than CD11b.

LP DC populations are dependent on FLT3L for development and are derived from a committed pre-cDC progenitor (Figure 1). Some pre-cDC can acquire expression of $\alpha 4 \beta 7$ integrin and thereby commit to an intestinal cDC fate $(16,19,20)$. LP cDCs express the cDC-specific transcription factor Zbtb46 (11) but not the macrophage marker CD64. Critically, all have the capacity to migrate in a CCR7-dependent manner to draining $\mathrm{LN}$ to interact with recirculating T cells $(26,27)$. LP cDC subsets require different transcription factors for development and their selective deletion has enabled some of their functions to be defined (Figure 1). Detailed discussion of these experiments is beyond the scope of this review but the reader is referred to other recent authoritative articles $(21,22)$.

\section{Antigen Sampling}

To protect against luminal pathogens and establish regulatory response to innocuous antigens, DCs continuously sample intestinal contents $(28,29)$. In PP, microfold (M) cells in the follicle associated epithelium internalize bacteria and other particulates and deliver them to underlying DCs [reviewed in (30)]. PP cDCs can also capture translocated IgA immune complexes (31) and extend dendrites through $M$ cell specific transcellular pores (32). cDCs cross-present viral antigen captured from infected epithelial cells $(33,34)$. Ileal CD103+ cDCs in the epithelium (Figure 1) sample soluble and particulate antigen (35). Transport of low molecular weight soluble material by SI goblet cells (36) and retro-transport of IgG immune complexes across the epithelium (37) can also deliver antigen to cDCs. Non-migratory CX3CR1+ macrophages in the SI sample antigens via trans-epithelial processes (38-41) and hand on to migratory CD103+ cDCs (38). The functional significance of different modes of sampling and the impact of inflammation are poorly understood.

\section{Imprinting of Gut Tropism}

Lymphocytes activated in gut lymphoid tissue traffic to the intestinal mucosa because they express specific adhesion molecules and chemokine receptors. The integrin $\alpha 4 \beta 7$ binds MAdCAM-1 expressed by intestinal vascular endothelium and facilitates entry to both the colon and the SI. The chemokine receptor CCR9 is required for entry to the SI, where its ligand CCL25 is expressed (42). GPR15 is implicated in homing to the colon but there may be important differences between mice and humans with regard to its role in the trafficking of effector vs. regulatory $\mathrm{T}$ cell populations (43-45). These mechanisms facilitate lymphocyte homing to the intestine in the absence of overt inflammation and enable intestinal responses to be regulated independently of the systemic response. In mice, cDCs that have migrated from LP to mesenteric lymph nodes induce expression of $\alpha 4 \beta 7$ and CCR9 on T cells they activate (46-49) via production of all-trans retinoic acid (RA) (50). Only cDC from the intestine express the enzyme RALDH2 (encoded by aldh1a2), required for the generation of RA from dietary vitamin A, explaining the site-specific induction of gut tropism (50). Initial data suggested that only CD103+ cDC had imprinting activity $(15,46,51,52)$ but it has subsequently been detected in mouse CD103- cDCs (26). Also, both CD103+ and CD103cDCs in the human colon express ALDH1A2 (53). Stromal cells in mesenteric lymph nodes can also produce RA to reinforce the imprinting activity of migratory intestinal cDCs (54-56).

\section{Induction of Regulatory and Effector T Cell Responses}

In the steady-state, intestinal DCs can induce Treg. In the mouse SI, induction of gut tropic Treg directed against soluble antigens, by both CD103+CD11b+ and CD103+CD11b- DCs, occurs in the mesenteric LN (52) and underlies the long-recognized phenomenon of oral tolerance generated to such antigens (57). The ability of SI CD103+ cDC to generate Treg is dependent on their expression of the integrin $\alpha \mathrm{v} \beta 8$, which activates latent TGF $\beta$, and is enhanced by their production of RA (58-62). PDL1 and PD-L2 have also been implicated in generation of Treg by MLN cDC (63). It is notable that induction of tolerance to colonic antigens differs from tolerance in the SI in that it is induced in the iliac, not mesenteric, nodes, is mediated by CD103$\mathrm{CD} 11 \mathrm{~b}+\mathrm{cDC}$ and is independent DC-generated RA (16). The generation of Treg directed against commensal bacteria has been less studied. Nonetheless, in a cell transfer model, the rapid generation of Treg from naïve commensal-reactive transgenic CD4 T cells required Notch2-dependent but not Batf3-dependent cDC, suggesting that SIRP $\alpha+\mathrm{cDC} 2$, possibly CD103+CD11b+ cells, play a dominant role (7). 


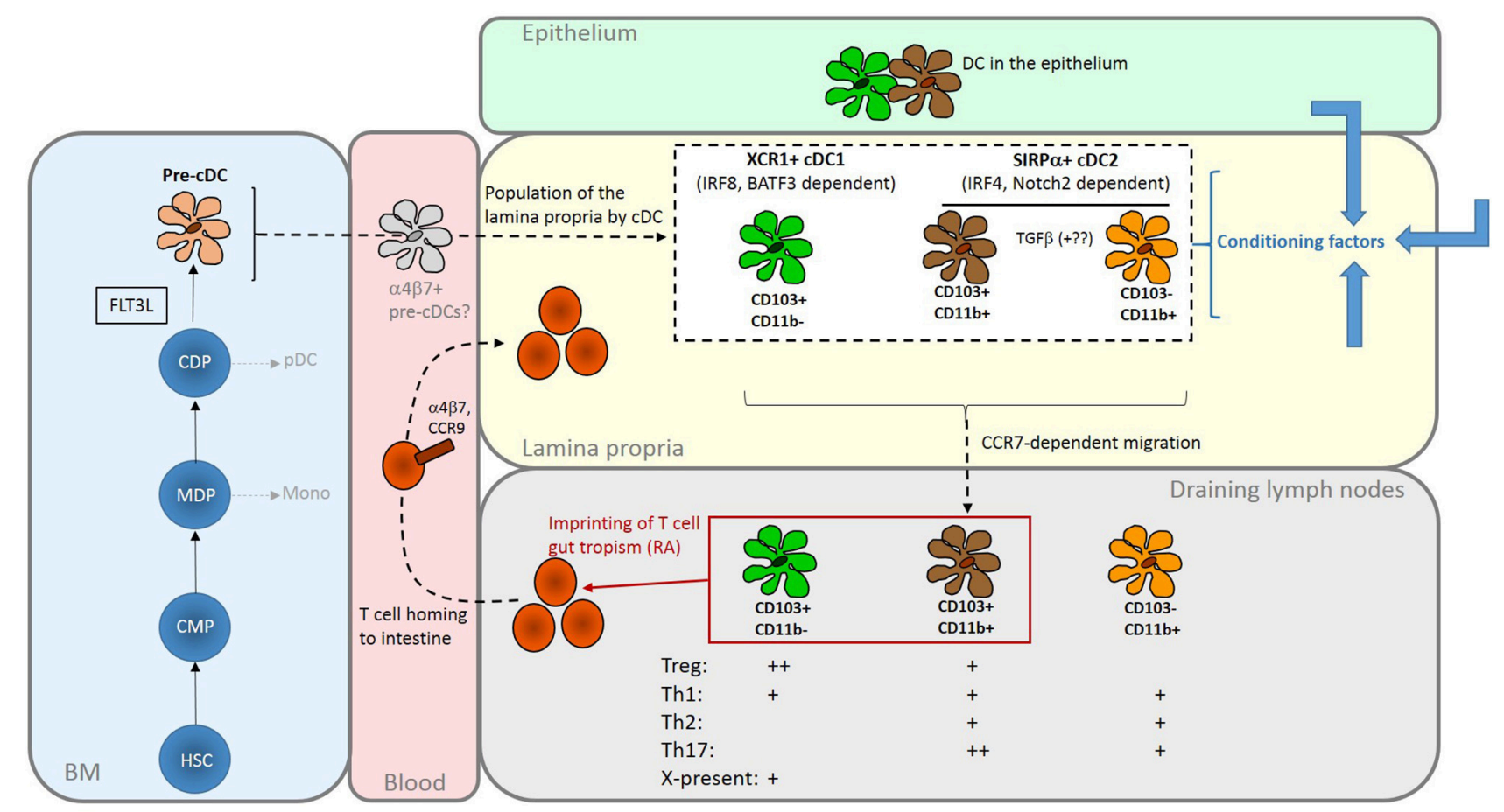

FIGURE 1 | Summary of the origins and properties of intestinal DC. FLT3L-dependent development of CDC gives rise to two major subsets via CDP and committed pre-CDC in the BM. CDC1 are XCR1 + and depend on transcription factors including IRF8 and BATF3; CDC2 are SIRP $\alpha+$ and depend on transcription factors that include IRF4. Population of the intestinal mucosa may be via an intermediate gut-committed $\alpha 4 \beta 7+$ precursor [sometimes termed pre-mucosal ( $\mu$ ) DC] stage (19, 20). In the mouse LP, the cDC2 population comprises two closely related CD11b+ subsets that can be distinguished by the presence or absence of CD103; $\mathrm{CD} 11 \mathrm{~b}+\mathrm{CD} 103+$, found predominately in the $\mathrm{SI}$, are probably derived from the CD11b+CD103- cells under the influence of TGF $\beta$. The CDC1 population is CD11b-CD103+. Similar populations in the human intestine can be identified on the basis of CD103 and SIRP $\alpha$ expression. In the LP they are exposed to conditioning factors (shown as blue arrows) from epithelial cells and other sources which further shape their functional properties. All three subsets have the capacity to migrate to draining lymph nodes to interact with recirculating T cells. Here, production of RA by LP- derived DCs, particularly those expressing CD103, imprints gut tropism on $T$ cells they activate by inducing expression of $\alpha 4 \beta 7$ integrin and the chemokine receptor CCR9. Although DCs can induce both Treg and effector T cells, with some specialism across DC subsets, the balance of these outcomes favors regulation in the steady-state. The reader is referred to recent reviews for a more in-depth discussion of intestinal DC subsets $(21,22)$. HSC, haematopoietic stem cell; CMP, common myeloid progenitor; MDP, monocyte dendritic cell precursor; CDP, common dendritic cell precursor; pDC, plasmacytoid DC; Mono, monocyte; X-present, cross-presentation to CD8+ T cells.

$\mathrm{T}$ cell responses stimulated by DCs in the steady-state are not exclusively regulatory. Effector $\mathrm{T}$ cells are present in the lamina propria of healthy mice and humans; although some of these may reflect past pathogen encounter others are specific for the commensal microbiota $(64,65)$. Effector cells in the healthy intestine enhance the epithelial barrier (66) and protect against translocation of pathogens (67). Their activity can be locally controlled by regulatory CX3CR $1^{\text {hi }}$ mucosal myeloid populations (68), anti-inflammatory cytokines such as TGF $\beta$ (69) as well as Treg. CD103- cDC migrating from the mouse SI can prime effector $\mathrm{T}$ cells in the absence of stimulation (26) indicating one mechanism by which these responses can be generated.

\section{Conditioning of Intestinal DC}

The ability of intestinal $c D C$ to generate $\mathrm{RA}$ and promote tolerance requires active $\mathrm{Wnt} / \beta$-catenin signaling with the $\mathrm{CDCs}$ (70) and is determined in part by local environment cues (71). Epithelial cells promote the ability of DC to generate both regulatory $(72,73)$ and Type 2 responses $(74)$. In the mouse, epithelial TSLP, with IL-25 and IL-33, inhibits IL-12 production by DCs and promotes their ability to generate Th2 responses that clear Trichuris muris infection (74). RA and TGF $\beta$ from human epithelial cells promote regulatory DC function (72). Exposure to RA can induce characteristics of SI DCs in vitro (75) and is required for aldh1a2 expression (76). Sources of RA include epithelial cells (77), LP stromal cells (78), and bile retinoids (79). In contrast, prostaglandin E2 has been reported to negatively regulate the expression of RA generating enzymes in DC (80). Dietary and microbial products, including ligands of the aryl hydrocarbon receptor [AhR (81)] and butyrate (82), also affect intestinal DCs.

\section{INTESTINAL DENDRITIC CELLS IN THE PROMOTION OF EFFECTOR FUNCTION AND INFLAMMATION}

\section{Promotion of Effector Function}

The balance of responses induced by DC can change in the context of infection to favor effector mechanisms. Signaling 
through p38 MAPK in CD103+ mouse DC regulates the balance of Treg and Th1 development from naïve T cells (83); in its absence, expression of RALDH2 and generation of Treg are reduced but Th1 responses enhanced.

A change in the balance of $\mathrm{T}$ cell responses induced by intestinal $\mathrm{CDC}$ may result from direct modulation by danger signals, altered conditioning of the resident CDC population or recruitment of distinct pro-inflammatory DC (Figure 2). Intestinal cDC express pattern recognition receptors and respond to microbial products $(84,85)$. Subsets of mouse and human DC differentially express Toll-like receptors (TLRs) suggesting specialization for direct recognition of particular microbes (25, 86). Mouse CD103+CD11b+ cDCs express TLR5 and their ability to induce Th17 responses is enhanced following activation with flagellin $(24,85,87,88)$. Activation of CD103+CD11b+ CDC results in increased production of IL- 6 and IL-23 which promote Th17 development and production of the anti-microbial peptide RegIII $\gamma(85,89)$. Administration of a TLR7 agonist in vivo results in activation of a CD103+CD11b- $\mathrm{CDC}$ migratory subset with the ability to generate effector CD8 $+\mathrm{T}$ cell responses to cross-presented antigen (90).

In most tissues, exposure to microbial products is sufficient to convert immature cDCs to mature cells which generate potent effector responses. However, exposure to PAMPs from the commensal microbiota is likely to be a common occurrence in the healthy intestine and therefore a second signal may also be required. Indeed, mouse CD103+ SI cDCs can induce Treg even in the presence of the high level of costimulatory molecule expression characteristic of mature $\mathrm{cDC}$ (58). The nature of this second signal is not known but IgA-containing immune complexes, normally restricted to the lumen, but present in significant quantities in damaged tissues, can enhance the proinflammatory activity of DCs (91).

Intestinal cDCs reside in the mucosa for a few days (92) during which time they are conditioned to acquire regulatory properties. cDCs that escape conditioning in the steady-state may facilitate the generation of "tonic" protective effector T cell responses. An increase in turnover following exposure to TLR ligands $(93,94)$ or inflammatory cytokines could shorten residence time, reduce exposure to conditioning factors and increase CDC-generated effector responses.

Intestinal cDC function may also be influenced remotely during their development in the bone marrow. Intestinal inflammation alters hematopoiesis to influence the development of monocytes and subsequently the intestinal populations derived from them (95). These concepts remain to be explored for $\mathrm{cDCs}$ but changes in blood DCs have been described in $\operatorname{IBD}(96,97)$.

Alternative precursors may also be recruited into the tissue under inflammatory conditions to provide cells with the ability to generate effector responses. Monocytes can give rise to DClike cells (monocyte-derived DC; moDC) under inflammatory conditions $(98,99)$. In healthy mice, monocytes recruited into the intestine differentiate into anti-inflammatory macrophages (100-103). However, under inflammatory conditions this differentiation process is interrupted, generating a population with some DC-like properties including the ability to activate naïve $\mathrm{T}$ cells and generate Th1 cells (102). Similarly, cells expressing the monocyte marker $\mathrm{CD} 14$ accumulate in the inflamed mucosa of inflammatory bowel disease (IBD) patients $(104,105)$ and these too have a high capacity to naive stimulate $\mathrm{T}$ cells and generate gut tropic Th1 cells and Th17 cells (104). However, it is unclear if monocyte derived-cells can migrate to lymphnodes or act solely within the mucosa.

Effector cells generated by DCs could also be released from local control within the tissues where diverse antigen presenting cell (APC) populations exert a local influence $(68,106-110)$. In the context of chronic inflammation, $\mathrm{T}$ cells lose responsiveness to regulatory TGF $\beta$ due to over-expression of SMAD7, an inhibitor of TGF $\beta$ R signaling (69). In addition, inflammatory cytokines can change the repertoire of peptides presented by DCs (111) and the emergence of "cryptic" determinants may allow escape from Treg control.

Irrespective of the combination of mechanisms which allow effector responses to be enhanced to deal with infections, a key unanswered question remains how these responses are confined to the pathogen and do not normally extend to co-sampled commensal organisms.

\section{DC and Inflammatory Intestinal Disease}

Many immune pathways key to IBD pathogenesis, highlighted by the identification of genetic variants associated with disease susceptibility, can be mapped to DCs. Nucleotide-binding oligomerization domain-containing-2 (NOD2), loss of function variants of which are associated with Crohn's disease (CD), is a bacterial sensor in DCs; its engagement impacts upon bacterial handling, cytokine production and antigen presentation (112, 113). DCs that express CD-associated variants are defective in these pathways $(112,113)$. The IL-23 axis is implicated in CD and DCs are a major source of bacterially driven intestinal IL$23(85,87,89)$. Moreover, expression of genes associated with variation in $\mathrm{CD}$ prognosis, rather than susceptibility, can also be mapped to DCs (114).

Mouse models of colitis provide direct evidence for the importance of DCs. Transfer of bone marrow derived DCs increases inflammation whereas depletion of DCs reduces it (115, 116). Colitis develops in mice in which TGF $\beta$ receptor signaling is non-functional in DCs $(23,117)$ and, in T cell deficient mice, administration of an agonistic anti-CD40 antibody activates DCs and induces IL-23-dependent intestinal inflammation (118).

DCs isolated from inflamed intestinal tissue show evidence of enhanced microbial recognition and heightened activation. More colonic cDCs from inflamed tissue of IBD patients express $\operatorname{TLR} 2$ and TLR4 $(119,120)$ and they also express higher levels of activation-associated CD40 (119). In CD, mature CCR7+ DCs, retained in the mucosa by locally produced ligands, cluster with proliferating T cells (121).

In $\mathrm{CD}$, more colonic LP cDCs produce IL-12/23p40 and IL6 but the proportion of $\mathrm{CDCs}$ that produce IL-10 is similar to healthy controls (119). Production of pro-inflammatory cytokines by colonic CDCs in CD correlates with disease activity, levels of inflammation and aspects of the intestinal microbiota (122). In UC, the frequency of cDCs producing IL-12/23p40 and IL-10 has been reported to be greater (122) or similar (119) to healthy controls in different studies. Production of IL- 6 by cDC 


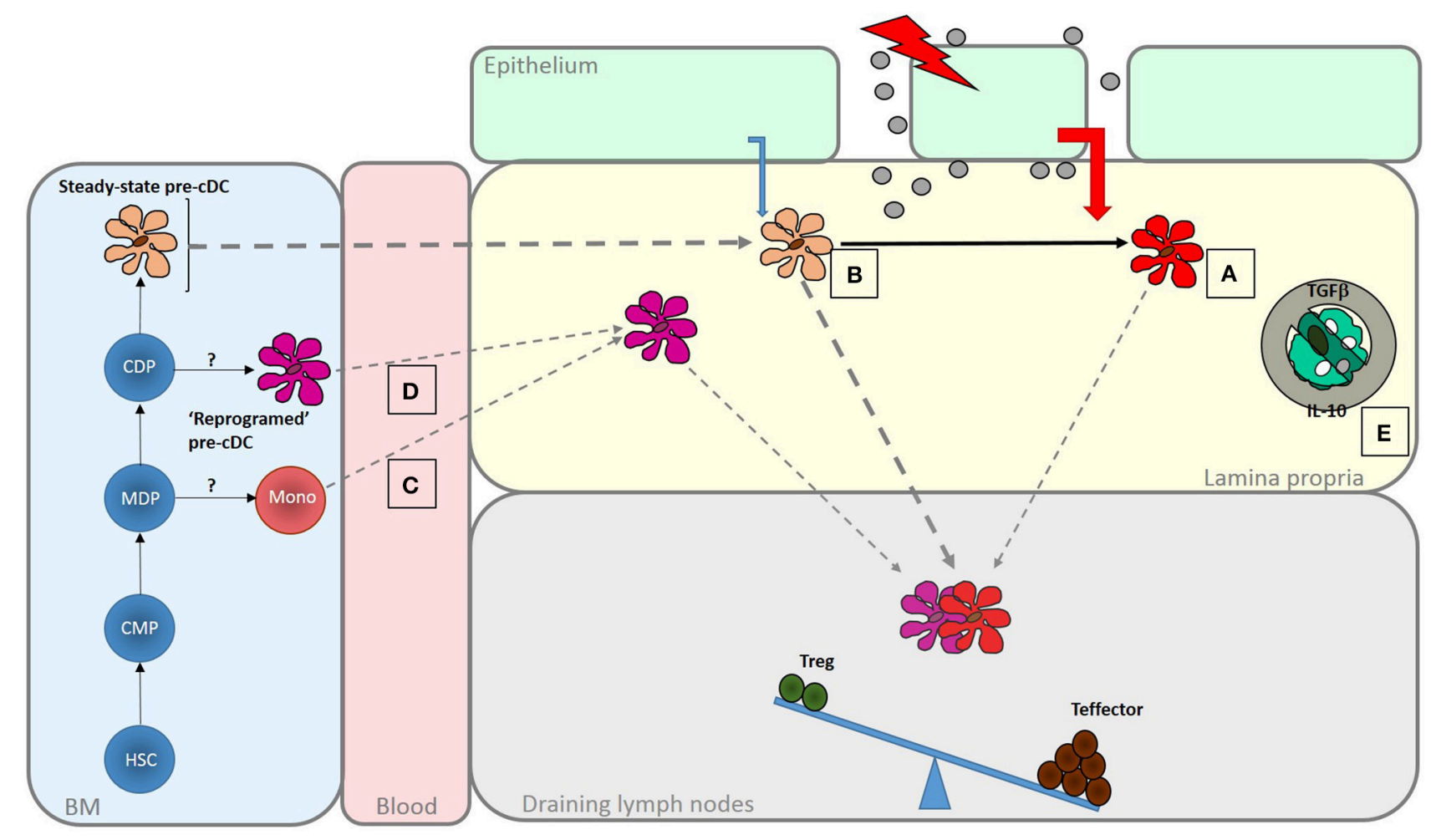

FIGURE 2 | Enhanced generation of effector T cells in response in infection and inflammatory disease. A number of mechanisms act to shift the balance of response induced by intestinal DC to favor the generation of effector responses. These are important for pathogen clearance but if dysregulated may lead to inflammatory disease. Increased exposure to PAMPS and DAMPS, as the result of loss of barrier integrity or tissue penetration by pathogens may be sensed by LP DC populations leading to their activation (A). Altered microbial sensing by epithelial cells due, for instance, to engagement of basolateral PRRs, may change the nature of conditioning factors they produce. Increased DC turnover may reduce exposure to those conditioning factors that normally promote regulatory function in intestinal DC (B). Alternatively, different types of DC, specialized to promote effector responses, may be recruited to the intestine under these conditions. These could be DC-like cells derived from monocytes (C) or possibly "reprogrammed" DC arise as a result of altered differentiation in the BM (D). There may also be a release from the regulatory mechanisms that normally limit effector function within the mucosa, due, for instance to a loss of response to regulatory cytokines like IL-10 or TGF $\beta$ or a failure to interact with CX3CR1 + cells that promote regulation (E). The role of DCs on determining responsiveness to these local control mechanisms is not known.

from UC patients was not increased in either study. In coeliac disease, activated DC producing Th1-promoting cytokines accumulate in the duodenal mucosa (123). In the MLN of CD patients, DCs release more IL-23 upon bacterial stimulation and CD4+ T cells produce more IL-17 and IFN $\gamma$ (124).

MicroRNAs are short non-coding RNA molecules that function in RNA silencing and post-transcriptional regulation of gene expression. Expression of microRNA (miR)-10a, which acts in DC to limit their ability to produce IL-23/23p40 and generate Th1 and Th17 responses, is reduced in the inflamed mucosa of IBD patients (125). The IBD-associated reduction in mir-10a is accompanied by increased expression of IL-12/23. In UC, immature colonic DCs are poorly stimulatory but induce an atypical $\mathrm{T}$ cell response characterized by increased IL- 4 but reduced IFN $\gamma$ and IL-22 $(120,126)$ possibly indicating a reduced ability to induce barrier protective $\mathrm{T}$ cell responses.

Numbers of CD103 + cDCs are reduced in mice with chronic ileitis (127) and in the colon of UC patients (128). Whether these differences reflect a change in phenotype or altered cDC populations is not clear. Unlike equivalent cDCs from normal human colon, CD103+ colonic cDCs from UC patients do not generate Foxp3 + Treg but do generate IFN $\gamma$-, IL-13-, and IL17-producing CD4 T cells. CD103+ cDCs from UC patients also have higher expression of IL-6, IL-12p40, IL-12p35, and $\mathrm{TNF} \alpha$ (128).

RA is required for optimal Treg induction by intestinal CD103+ cDCs in the steady-state but these cells have reduced expression of RA-generating enzymes in mice with colitis (127, 129). The effects of RA on the immune system are context dependent [reviewed in $(130,131)]$ and it can promote proinflammatory as well as regulatory responses (132). In the presence of IL-15, RA induces the release of pro-inflammatory IL-12 and IL-23 by cDC and promotes intestinal inflammation (133). There is conflicting data on the production of RA by DC in the inflamed human colon: increased (53) and decreased (134) expression of RA-generating enzymes have both been reported in IBD. It should be borne in mind that neither study measured RA itself nor assessed other factors that regulate RA availability, such as expression of CYP26 enzymes that degrade RA (135). 


\section{CONCLUDING REMARKS}

Antibodies which target $\alpha 4 \beta 7$, an integrin which can be imprinted by intestinal DCs to facilitate $\mathrm{T}$ cell entry to the intestine, are already used to treat IBD. DCs also control the balance between regulatory and effector $\mathrm{T}$ cell responses in the intestine. Understanding the mechanisms involved and their regulation will facilitate rational manipulation of DCs to promote effector responses in the context of infection and vaccination or to re-establish regulation in the context of inflammatory disease.

\section{REFERENCES}

1. Guilliams M, Ginhoux F, Jakubzick C, Naik SH, Onai N, Schraml BU, et al. Dendritic cells, monocytes and macrophages: a unified nomenclature based on ontogeny. Nat Rev Immunol. (2014) 14:571-8. doi: 10.1038/nri3712

2. Scott CL, Bain CC, Mowat AM. Isolation and identification of intestinal myeloid cells. Methods Mol Biol. (2017) 1559:223-39. doi: 10.1007/978-1-4939-6786-5_15

3. Scott CL, Wright PB, Milling SW, Mowat AM. Isolation and identification of conventional dendritic cell subsets from the intestine of mice and men. Methods Mol Biol. (2016) 1423:101-18. doi: 10.1007/978-1-4939-3606-9_7

4. Lombardi VC, Khaiboullina SF. Plasmacytoid dendritic cells of the gut: relevance to immunity and pathology. Clinical immunology (2014) 153:16577. doi: 10.1016/j.clim.2014.04.007

5. Esterhazy D, Loschko J, London M, Jove V, Oliveira TY, Mucida D. Classical dendritic cells are required for dietary antigen-mediated induction of peripheral Treg cells and tolerance. Nat Immunol. (2016) 17:545-55. doi: $10.1038 /$ ni.3408

6. Loschko J, Schreiber HA, Rieke GJ, Esterhazy D, Meredith MM, Pedicord $\mathrm{VA}$, et al. Absence of MHC class II on cDCs results in microbialdependent intestinal inflammation. J Exp Med. (2016) 213:517-34. doi: 10.1084/jem.20160062

7. Nutsch K, Chai JN, Ai TL, Russler-Germain E, Feehley T, Nagler CR, et al. Rapid and efficient generation of regulatory $\mathrm{T}$ cells to commensal antigens in the periphery. Cell Rep. (2016) 17:206-20. doi: 10.1016/j.celrep.2016. 08.092

8. Gao Y, Nish SA, Jiang R, Hou L, Licona-Limon P, Weinstein JS, et al. Control of $\mathrm{T}$ helper 2 responses by transcription factor IRF4-dependent dendritic cells. Immunity (2013) 39:722-32. doi: 10.1016/j.immuni.2013. 08.028

9. Mayer JU, Demiri M, Agace WW, MacDonald AS, Svensson-Frej M, Milling SW. Different populations of $\mathrm{CD}_{11 \mathrm{~b}}{ }^{+}$dendritic cells drive Th2 responses in the small intestine and colon. Nat Commun. (2017) 8:15820. doi: $10.1038 /$ ncomms 15820

10. Meredith MM, Liu K, Darrasse-Jeze G, Kamphorst AO, Schreiber HA, Guermonprez P, et al. Expression of the zinc finger transcription factor zDC (Zbtb46, Btbd4) defines the classical dendritic cell lineage. J Exp Med. (2012) 209:1153-65. doi: 10.1084/jem.20112675

11. Satpathy AT, Briseno CG, Lee JS, $\mathrm{Ng} \mathrm{D,} \mathrm{Manieri} \mathrm{NA,} \mathrm{Kc} \mathrm{W,} \mathrm{et} \mathrm{al.}$ Notch2-dependent classical dendritic cells orchestrate intestinal immunity to attaching-and-effacing bacterial pathogens. Nat Immunol. (2013) 14:937-48. doi: 10.1038/ni.2679

12. Sun T, Rojas OL, Li C, Ward LA, Philpott DJ, Gommerman JL. Intestinal Batf3-dependent dendritic cells are required for optimal antiviral T-cell responses in adult and neonatal mice. Mucosal Immunol. (2017) 10:775-88. doi: $10.1038 / \mathrm{mi} .2016 .79$

13. Kelsall BL, Strober W. Distinct populations of dendritic cells are present in the subepithelial dome and T cell regions of the murine Peyer's Patch. J Exp Med. (1996) 183:237-47. doi: 10.1084/jem.183.1.237

14. Chirdo FG, Millington OR, Beacock-Sharp H, Mowat AM. Immunomodulatory dendritic cells in intestinal lamina propria. Eur J Immunol. (2005) 35:1831-40. doi: 10.1002/eji.200425882

\section{AUTHOR CONTRIBUTIONS}

The author confirms being the sole contributor of this work and has approved it for publication.

\section{FUNDING}

Work from the author's own laboratory mentioned in this article was funded by the Broad Medical Research Programme, Crohn's in Childhood Research Association and a MRC Doctoral Training Award.

15. Jaensson E, Uronen-Hansson H, Pabst O, Eksteen B, Tian J, Coombes JL, et al. Small intestinal CD103+ dendritic cells display unique functional properties that are conserved between mice and humans. J Exp Med. (2008) 205:2139-49. doi: 10.1084/jem.20080414

16. Veenbergen S, van Berkel LA, du Pre MF, He J, Karrich JJ, Costes LM, et al. Colonic tolerance develops in the iliac lymph nodes and can be established independent of CD103(+) dendritic cells. Mucosal Immunol. (2016) 9:894-906. doi: 10.1038/mi.2015.118

17. Gurka S, Hartung E, Becker M, Kroczek RA. Mouse conventional dendritic cells can be universally classified based on the mutually exclusive expression of XCR1 and SIRP $\alpha$. Front Immunol. (2015) 6:35. doi: 10.3389/fimmu.2015.00035

18. Becker M, Guttler S, Bachem A, Hartung E, Mora A, Jakel A, et al. Ontogenic, phenotypic, and functional characterization of XCR1(+) dendritic cells leads to a consistent classification of intestinal dendritic cells based on the expression of XCR1 and SIRP $\alpha$. Front Immunol. (2014) 5:326. doi: 10.3389/fimmu.2014.00326

19. Villablanca EJ, De Calisto J, Torregrosa Paredes P, Cassani B, Nguyen DD, Gabrielsson S, et al. $\beta 7$ integrins are required to give rise to intestinal mononuclear phagocytes with tolerogenic potential. Gut (2014) 63:1431-40. doi: 10.1136/gutjnl-2013-305386

20. Zeng R, Oderup C, Yuan R, Lee M, Habtezion A, Hadeiba H, et al. Retinoic acid regulates the development of a gut-homing precursor for intestinal dendritic cells. Mucosal Immunol. (2013) 6:847-56. doi: 10.1038/mi.2012.123

21. Bekiaris V, Persson EK, Agace WW. Intestinal dendritic cells in the regulation of mucosal immunity. Immunol Rev. (2014) 260:86-101. doi: 10.1111/imr.12194

22. Joeris T, Muller-Luda K, Agace WW, Mowat AM. Diversity and functions of intestinal mononuclear phagocytes. Mucosal Immunol. (2017) 10:845-64. doi: $10.1038 / \mathrm{mi} .2017 .22$

23. Bain CC, Montgomery J, Scott CL, Kel JM, Girard-Madoux MJH, Martens L, et al. TGF $\beta$ R signalling controls $\mathrm{CD}_{103}{ }^{+} \mathrm{CD} 11 \mathrm{~b}^{+}$dendritic cell development in the intestine. Nat Commun. (2017) 8:620. doi: 10.1038/s41467-017-00658-6

24. Denning TL, Norris BA, Medina-Contreras O, Manicassamy S, Geem D, Madan R, et al. Functional specializations of intestinal dendritic cell and macrophage subsets that control Th17 and regulatory $\mathrm{T}$ cell responses are dependent on the $\mathrm{T}$ cell/APC ratio, source of mouse strain, and regional localization. J Immunol. (2011) 187:733-47. doi: 10.4049/jimmunol.1 002701

25. Watchmaker PB, Lahl K, Lee M, Baumjohann D, Morton J, Kim SJ, et al. Comparative transcriptional and functional profiling defines conserved programs of intestinal DC differentiation in humans and mice. Nat Immunol. (2014) 15:98-108. doi: 10.1038/ni.2768

26. Cerovic V, Houston SA, Scott CL, Aumeunier A, Yrlid U, Mowat AM, et al. Intestinal CD103(-) dendritic cells migrate in lymph and prime effector T cells. Mucosal Immunol. (2012) 6:104-13. doi: 10.1038/mi. 2012.53

27. Jang MH, Sougawa N, Tanaka T, Hirata T, Hiroi T, Tohya K, et al CCR7 is critically important for migration of dendritic cells in intestinal lamina propria to mesenteric lymph nodes. J Immunol. (2006) 176:803-10. doi: 10.4049/jimmunol.176.2.803 
28. Liu LM, Macpherson GG. Lymph-borne (veiled) dendritic cells can acquire and present intestinally administered antigens. Immunology (1991) 73:281-6.

29. Liu LM, MacPherson GG. Antigen acquisition by dendritic cells: intestinal dendritic cells acquire antigen administered orally and can prime naive $\mathrm{T}$ cells in vivo. J Exp Med. (1993) 177:1299-307. doi: 10.1084/jem.177.5.1299

30. Schulz O, Pabst O. Antigen sampling in the small intestine. Trends Immunol. (2012) 34:151-61. doi: 10.1016/j.it.2012.09.006

31. Kadaoui KA, Corthesy B. Secretory IgA mediates bacterial translocation to dendritic cells in mouse Peyer's patches with restriction to mucosal compartment. J Immunol. (2007) 179:7751-7. doi: 10.4049/jimmunol.179.11.7751

32. Lelouard H, Fallet M, de Bovis B, Méresse S, Gorvel JP. Peyer's Patch dendritic cells sample antigens by extending dendrites through $\mathrm{m}$ cellspecific transcellular pores. Gastroenterology (2012) 142:592-601.e593. doi: 10.1053/j.gastro.2011.11.039

33. Fleeton MN, Contractor N, Leon F, Wetzel JD, Dermody TS, Kelsall BL. Peyer's patch dendritic cells process viral antigen from apoptotic epithelial cells in the intestine of reovirus-infected mice. J Exp Med. (2004) 200:235-45. doi: 10.1084/jem.20041132

34. Huang FP, Platt N, Wykes M, Major JR, Powell TJ, Jenkins CD, et al. A discrete subpopulation of dendritic cells transports apoptotic intestinal epithelial cells to t cell areas of mesenteric lymph nodes. J Exp Med. (2000) 191:435-44. doi: 10.1084/jem.191.3.435

35. Farache J, Koren I, Milo I, Gurevich I, Kim KW, Zigmond E, et al. Luminal bacteria recruit $\mathrm{CD} 103+$ dendritic cells into the intestinal epithelium to sample bacterial antigens for presentation. Immunity (2013) 38:581-95. doi: 10.1016/j.immuni.2013.01.009

36. McDole JR, Wheeler LW, McDonald KG, Wang B, Konjufca V, Knoop KA, et al. Goblet cells deliver luminal antigen to CD103+ dendritic cells in the small intestine. Nature (2012) 483:345-9. doi: 10.1038/nature10863

37. Yoshida M, Claypool SM, Wagner JS, Mizoguchi E, Mizoguchi A, Roopenian DC, et al. Human neonatal Fc receptor mediates transport of IgG into luminal secretions for delivery of antigens to mucosal dendritic cells. Immunity (2004) 20:769-83. doi: 10.1016/j.immuni.2004.05.007

38. Mazzini E, Massimiliano L, Penna G, Rescigno M. Oral tolerance can be established via gap junction transfer of fed antigens from CX3CR1 ${ }^{+}$ macrophages to $\mathrm{CD} 103^{+}$dendritic cells. Immunity (2014) 40:248-61. doi: 10.1016/j.immuni.2013.12.012

39. Niess JH, Brand S, Gu X, Landsman L, Jung S, McCormick BA, et al. CX3CR1-mediated dendritic cell access to the intestinal lumen and bacterial clearance. Science (2005) 307:254-8. doi: 10.1126/science.1102901

40. Rescigno M, Urbano M, Valzasina B, Francolini M, Rotta G, Bonasio R, et al. Dendritic cells express tight junction proteins and penetrate gut epithelial monolayers to sample bacteria. Nat Immunol. (2001) 2:361-7. doi: $10.1038 / 86373$

41. Vallon-Eberhard A, Landsman L, Yogev N, Verrier B, Jung S. Transepithelial pathogen uptake into the small intestinal lamina propria. J Immunol. (2006) 176:2465-9. doi: 10.4049/jimmunol.176.4.2465

42. Mora JR, Von Andrian UH. T-cell homing specificity and plasticity: new concepts and future challenges. Trends Immunol. (2006) 27:235-43. doi: 10.1016/j.it.2006.03.007

43. Fischer A, Zundler S, Atreya R, Rath T, Voskens C, Hirschmann S, et al. Differential effects of $\alpha 4 \beta 7$ and GPR15 on homing of effector and regulatory $\mathrm{T}$ cells from patients with UC to the inflamed gut in vivo. Gut (2016) 65:1642-64. doi: 10.1136/gutjnl-2015-310022

44. Kim SV, Xiang WV, Kwak C, Yang Y, Lin XW, Ota M, et al. GPR15-mediated homing controls immune homeostasis in the large intestine mucosa. Science (2013) 340:1456-9. doi: 10.1126/science.1237013

45. Nguyen LP, Pan J, Dinh TT, Hadeiba H, O’Hara Iii E, Ebtikar A, et al. Role and species-specific expression of colon T cell homing receptor GPR15 in colitis. Nat Immunol. (2015) 16:207-13. doi: 10.1038/ni.3079

46. Johansson-Lindbom B, Svensson M, Pabst O, Palmqvist C, Marquez G, Forster R, et al. Functional specialization of gut $\mathrm{CD}_{103}{ }^{+}$dendritic cells in the regulation of tissue-selective T cell homing. J Exp Med. (2005) 202:1063-73. doi: 10.1084 /jem. 20051100

47. Johansson-Lindbom B, Svensson M, Wurbel MA, Malissen B, Marquez $\mathrm{G}$, Agace W. Selective generation of gut tropic T cells in gut-associated lymphoid tissue (GALT): requirement for GALT dendritic cells and adjuvant. J ExpMed. (2003) 198:963-9. doi: 10.1084/jem.20031244

48. Mora JR, Bono MR, Manjunath N, Weninger W, Cavanagh LL, Rosemblatt $\mathrm{M}$, et al. Selective imprinting of gut-homing T cells by Peyer's patch dendritic cells. Nature (2003) 424:88-93. doi: 10.1038/nature01726

49. Stagg AJ, Kamm MA, Knight SC. Intestinal dendritic cells increase $\mathrm{T}$ cell expression of $\alpha 4 \beta 7$ integrin. EurJ Immunol. (2002) 32:1445-54. doi: 10.1002/1521-4141(200205)32:5<1445::AID-IMMU1445>3.0.CO;2-E

50. Iwata M, Hirakiyama A, Eshima Y, Kagechika H, Kato C, Song SY. Retinoic acid imprints gut-homing specificity on T cells. Immunity (2004) 21:527-38. doi: 10.1016/j.immuni.2004.08.011

51. Annacker O, Coombes JL, Malmstrom V, Uhlig HH, Bourne T, JohanssonLindbom B, et al. Essential role for CD103 in the $\mathrm{T}$ cell-mediated regulation of experimental colitis. J Exp Med. (2005) 202:1051-61. doi: $10.1084 /$ jem.20040662

52. Welty NE, Staley C, Ghilardi N, Sadowsky MJ, Igyarto BZ, Kaplan DH. Intestinal lamina propria dendritic cells maintain $\mathrm{T}$ cell homeostasis but do not affect commensalism. J Exp Med. (2013) 210:2011-24. doi: $10.1084 /$ jem.20130728

53. Sanders TJ, McCarthy NE, Giles EM, Davidson KL, Haltalli ML, Hazell S, et al. Increased production of retinoic acid by intestinal macrophages contributes to their inflammatory phenotype in patients with Crohn's disease. Gastroenterology (2014) 146:1278-88. doi: 10.1053/j.gastro.2014.01.057

54. Hammerschmidt SI, Ahrendt M, Bode U, Wahl B, Kremmer E, Forster $\mathrm{R}$, et al. Stromal mesenteric lymph node cells are essential for the generation of gut-homing T cells in vivo. J Exp Med. (2008) 205:2483-90. doi: 10.1084/jem.20080039

55. Molenaar R, Greuter M, van der Marel AP, Roozendaal R, Martin SF, Edele F, et al. Lymph node stromal cells support dendritic cell-induced gut-homing of T cells. J Immunol. (2009) 183:6395-402. doi: 10.4049/jimmunol.09 00311

56. Molenaar R, Knippenberg M, Goverse G, Olivier BJ, de Vos AF, O’Toole $\mathrm{T}$, et al. Expression of retinaldehyde dehydrogenase enzymes in mucosal dendritic cells and gut-draining lymph node stromal cells is controlled by dietary vitamin A. J Immunol. (2011) 186:1934-42. doi: 10.4049/jimmunol.1001672

57. Mowat AM. To respond or not to respond - a personal perspective of intestinal tolerance. Nat Rev Immunol. (2018) 18:405-15. doi: 10.1038/s41577-018-0002-x

58. Benson MJ, Pino-Lagos K, Rosemblatt M, Noelle RJ. All-trans retinoic acid mediates enhanced $\mathrm{T}$ reg cell growth, differentiation, and gut homing in the face of high levels of co-stimulation. J Exp Med. (2007) 204:1765-74. doi: 10.1084/jem.20070719

59. Coombes JL, Siddiqui KRR, Arancibia-Carcamo CV, Hall J, Sun CM, Belkaid Y, et al. A functionally specialized population of mucosal CD103+ DCs induces Foxp3+ regulatory T cells via a TGF $\beta$ - and retinoic aciddependent mechanism. J Exp Med. (2007) 204:1757-64. doi: 10.1084/jem.200 70590

60. Mucida D, Park Y, Kim G, Turovskaya O, Scott I, Kronenberg M, et al. Reciprocal TH17 and regulatory $\mathrm{T}$ cell differentiation mediated by retinoic acid. Science (2007) 317:256-60. doi: 10.1126/science.1145697

61. Sun CM, Hall JA, Blank RB, Bouladoux N, Oukka M, Mora JR, et al. Small intestine lamina propria dendritic cells promote de novo generation of Foxp3 T reg cells via retinoic acid. J Exp Med. (2007) 204:1775-85. doi: 10.1084/jem.20070602

62. Worthington JJ, Czajkowska BI, Melton AC, Travis MA. Intestinal dendritic cells specialize to activate transforming growth factor- $\beta$ and induce Foxp $3+$ regulatory T cells via integrin $\alpha v \beta 8$. Gastroenterology (2011) 141:1802-12. doi: 10.1053/j.gastro.2011.06.057

63. Fukaya T, Takagi H, Sato Y, Sato K, Eizumi K, Taya H, et al. Crucial roles of B7-H1 and B7-DC expressed on mesenteric lymph node dendritic cells in the generation of antigen-specific CD4+Foxp3+ regulatory $\mathrm{T}$ cells in the establishment of oral tolerance. Blood (2010) 116:2266-76. doi: 10.1182/blood-2009-10-250472

64. Hegazy AN, West NR, Stubbington MJT, Wendt E, Suijker KIM, Datsi $\mathrm{A}$, et al. Circulating and tissue-resident $\mathrm{CD} 4+\mathrm{T}$ cells with reactivity to intestinal microbiota are abundant in healthy individuals and function is 
altered during inflammation. Gastroenterology (2017) 153:1320-1337.e1316. doi: 10.1053/j.gastro.2017.07.047

65. Ivanov II, Frutos Rde L, Manel N, Yoshinaga K, Rifkin DB, Sartor RB, et al. Specific microbiota direct the differentiation of IL-17-producing T-helper cells in the mucosa of the small intestine. Cell Host Microbe (2008) 4:337-49. doi: 10.1016/j.chom.2008.09.009

66. Muzaki AR, Tetlak P, Sheng J, Loh SC, Setiagani YA, Poidinger M, et al. Intestinal CD103(+)CD11b(-) dendritic cells restrain colitis via IFN- $\gamma$ induced anti-inflammatory response in epithelial cells. Mucosal Immunol. (2016) 9:336-51. doi: 10.1038/mi.2015.64

67. Edelblum KL, Sharon G, Singh G, Odenwald MA, Sailer A, Cao S, et al. The Microbiome Activates CD4 T-cell mediated immunity to compensate for increased intestinal permeability. Cell Mol Gastroenterol Hepatol. (2017) 4:285-97. doi: 10.1016/j.jcmgh.2017.06.001

68. Kayama H, Ueda Y, Sawa Y, Jeon SG, Ma JS, Okumura R, et al. Intestinal CX3C chemokine receptor 1(high) [CX3CR1(high)] myeloid cells prevent T-cell-dependent colitis. Proc Natl Acad Sci USA. (2012) 109:5010-5. doi: 10.1073/pnas.1114931109

69. Monteleone G, Kumberova A, Croft NM, McKenzie C, Steer HW, MacDonald TT. Blocking Smad7 restores TGF- $\beta 1$ signaling in chronic inflammatory bowel disease. J Clin Invest. (2001) 108:601-9. doi: $10.1172 / J C I 12821$

70. Manicassamy S, Reizis B, Ravindran R, Nakaya H, Salazar-Gonzalez RM, Wang YC, et al. Activation of $\beta$-catenin in dendritic cells regulates immunity versus tolerance in the intestine. Science (2010) 329:849-53. doi: $10.1126 /$ science. 1188510

71. Cassani B, Villablanca EJ, De Calisto J, Wang S, Mora JR. Vitamin A and immune regulation: role of retinoic acid in gut-associated dendritic cell education, immune protection and tolerance. Mol Aspects Med. (2012) 33:63-76. doi: 10.1016/j.mam.2011.11.001

72. Iliev ID, Mileti E, Matteoli G, Chieppa M, Rescigno M. Intestinal epithelial cells promote colitis-protective regulatory T-cell differentiation through dendritic cell conditioning. Mucosal Immunol. (2009) 2:340-50. doi: $10.1038 / \mathrm{mi} .2009 .13$

73. Iliev ID, Spadoni I, Mileti E, Matteoli G, Sonzogni A, Sampietro GM, et al. Human intestinal epithelial cells promote the differentiation of tolerogenic dendritic cells. Gut (2009) 58:481-9. doi: 10.1136/gut.2008.175166

74. Zaph C, Troy AE, Taylor BC, Berman-Booty LD, Guild KJ, Du Y, et al. Epithelial-cell-intrinsic IKK-beta expression regulates intestinal immune homeostasis. Nature (2007) 446:552-6. doi: 10.1038/nature05590

75. Zeng R, Bscheider M, Lahl K, Lee M, Butcher EC. Generation and transcriptional programming of intestinal dendritic cells: essential role of retinoic acid. Mucosal Immunol. (2016) 9:183-93. doi: 10.1038/mi.2015.50

76. Villablanca EJ, Wang S, de Calisto J, Gomes DC, Kane MA, Napoli JL, et al. MyD88 and retinoic acid signaling pathways interact to modulate gastrointestinal activities of dendritic cells. Gastroenterology (2011) 141:17685. doi: 10.1053/j.gastro.2011.04.010

77. McDonald KG, Leach MR, Brooke KW, Wang C, Wheeler LW, Hanly EK, et al. Epithelial expression of the cytosolic retinoid chaperone cellular retinol binding protein II is essential for in vivo imprinting of local gut dendritic cells by lumenal retinoids. Am J Pathol. (2012) 180:984-97. doi: 10.1016/j.ajpath.2011.11.009

78. Vicente-Suarez I, Larange A, Reardon C, Matho M, Feau S, Chodaczek $\mathrm{G}$, et al. Unique lamina propria stromal cells imprint the functional phenotype of mucosal dendritic cells. Mucosal Immunol. (2015) 8:141-51. doi: $10.1038 / \mathrm{mi} .2014 .51$

79. Jaensson-Gyllenback E, Kotarsky K, Zapata F, Persson EK, Gundersen TE, Blomhoff $\mathrm{R}$, et al. Bile retinoids imprint intestinal $\mathrm{CD}_{103^{+}}$dendritic cells with the ability to generate gut-tropic T cells. Mucosal Immunol. (2011) 4:438-47. doi: 10.1038/mi.2010.91

80. Stock A, Booth S, Cerundolo V. Prostaglandin E2 suppresses the differentiation of retinoic acid-producing dendritic cells in mice and humans. J Exp Med. (2011) 208:761-73 doi: 10.1084/jem.20101967

81. Chng SH, Kundu P, Dominguez-Brauer C, Teo WL, Kawajiri K, FujiiKuriyama Y, et al. Ablating the aryl hydrocarbon receptor (AhR) in CD11c+ cells perturbs intestinal epithelium development and intestinal immunity. Sci Rep. (2016) 6:23820. doi: 10.1038/srep23820
82. Singh N, Gurav A, Sivaprakasam S, Brady E, Padia R, Shi H, et al. Activation of Gpr109a, receptor for niacin and the commensal metabolite butyrate, suppresses colonic inflammation and carcinogenesis. Immunity (2014) 40:128-39. doi: 10.1016/j.immuni.2013.12.007

83. Huang G, Wang Y, Chi H. Control of T cell fates and immune tolerance by p38 $\alpha$ signaling in mucosal CD103+ dendritic cells. J Immunol. (2013) 191:650-9. doi: 10.4049/jimmunol.1300398

84. Cerovic V, Jenkins CD, Barnes AG, Milling SW, MacPherson GG, Klavinskis LS. Hyporesponsiveness of intestinal dendritic cells to TLR stimulation is limited to TLR4. J Immunol. (2009) 182:2405-15. doi: 10.4049/jimmunol.0802318

85. Kinnebrew MA, Buffie CG, Diehl GE, Zenewicz LA, Leiner I, Hohl TM, et al. Interleukin 23 production by intestinal $\mathrm{CD} 103(+) \mathrm{CD} 11 \mathrm{~b}(+)$ dendritic cells in response to bacterial flagellin enhances mucosal innate immune defense. Immunity (2012) 36:276-87. doi: 10.1016/j.immuni.2011.12.011

86. Fujimoto K, Karuppuchamy T, Takemura N, Shimohigoshi M, Machida T, Haseda Y, et al. A new subset of CD103+CD8alpha+ dendritic cells in the small intestine expresses TLR3, TLR7, and TLR9 and induces Th1 response and CTL activity. J Immunol. (2011) 186:6287-95. doi: 10.4049/jimmunol.1004036

87. Liu H, Chen F, Wu W, Cao AT, Xue X, Yao S, et al. TLR5 mediates CD172 $\alpha+$ intestinal lamina propria dendritic cell induction of Th17 cells. Sci Rep. (2016) 6:22040. doi: 10.1038/srep22040

88. Uematsu S, Fujimoto K, Jang MH, Yang B-G, Jung Y-J, Nishiyama M, et al. Regulation of humoral and cellular gut immunity by lamina propria dendritic cells expressing toll-like receptor 5. Nat Immunol. (2008) 9:769-76. doi: $10.1038 /$ ni. 1622

89. Persson EK, Uronen-Hansson H, Semmrich M, Rivollier A, Hagerbrand K, Marsal J, et al. IRF4 transcription-factor-dependent CD103(+)CD11b(+) dendritic cells drive mucosal $\mathrm{T}$ helper 17 cell differentiation. Immunity (2013) 38:958-69. doi: 10.1016/j.immuni.2013.03.009

90. Cerovic V, Houston SA, Westlund J, Utriainen L, Davison ES, Scott CL, et al. Lymph-borne $\mathrm{CD} 8 \alpha^{+}$dendritic cells are uniquely able to cross-prime $\mathrm{CD}^{+} \mathrm{T}$ cells with antigen acquired from intestinal epithelial cells. Mucosal Immunol. (2014) 8:38-48. doi: 10.1038/mi.2014.40

91. Hansen IS, Krabbendam L, Bernink JH, Loayza-Puch F, Hoepel W, van Burgsteden JA, et al. FcaRI co-stimulation converts human intestinal $\mathrm{CD} 103+$ dendritic cells into pro-inflammatory cells through glycolytic reprogramming. Nat Commun. (2018) 9:863. doi: 10.1038/s41467-018-03318-5

92. Pugh CW, MacPherson GG, Steer HW. Characterization of nonlymphoid cells derived from rat peripheral lymph. J Exp Med. (1983) 157:1758-79. doi: 10.1084/jem.157.6.1758

93. Turnbull EL, Yrlid U, Jenkins CD, MacPherson GG. Intestinal dendritic cell subsets: differential effects of systemic TLR4 stimulation on migratory fate and activation in vivo. J Immunol. (2005) 174:1374-84. doi: 10.4049/jimmunol.174.3.1374

94. Yrlid U, Milling SWF, Miller JL, Cartland S, Jenkins CD, MacPherson GG. Regulation of intestinal dendritic cell migration and activation by plasmacytoid dendritic cells, TNF-alpha and type 1 IFNs after feeding a TLR7/8 ligand. J Immunol. (2006) 176:5205-12. doi: 10.4049/jimmunol.176.9.5205

95. Askenase MH, Han SJ, Byrd AL, Morais da Fonseca D, Bouladoux $\mathrm{N}$, Wilhelm $\mathrm{C}$, et al. Bone-marrow-resident NK cells prime monocytes for regulatory function during infection. Immunity (2015) 42:1130-42. doi: 10.1016/j.immuni.2015.05.011

96. Baumgart DC, Thomas S, Przesdzing I, Metzke D, Bielecki C, Lehmann SM, et al. Exaggerated inflammatory response of primary human myeloid dendritic cells to lipopolysaccharide in patients with inflammatory bowel disease. Clin Exp Immunol. (2009) 157:423-36. doi: 10.1111/j.1365-2249.2009.03981.x

97. Peake ST, Bernardo D, Knight SC, Hart AL. Homing marker expression on circulating dendritic cells correlates with different phenotypes of Crohn's disease. J Crohns Colitis (2013) 7:594-6. doi: 10.1016/j.crohns.2012.10.002

98. Jakubzick CV, Randolph GJ, Henson PM. Monocyte differentiation and antigen-presenting functions. Nat Rev Immunol. (2017) 17:349-62. doi: $10.1038 /$ nri.2017.28 
99. Menezes S, Melandri D, Anselmi G, Perchet T, Loschko J, Dubrot J, et al. The heterogeneity of Ly6 $\mathrm{C}^{\text {hi }}$ monocytes controls their differentiation into iNOS+ macrophages or monocyte-derived dendritic cells. Immunity (2016) 45:1205-18. doi: 10.1016/j.immuni.2016.12.001

100. Bain CC, Bravo-Blas A, Scott CL, Gomez Perdiguero E, Geissmann F, Henri $\mathrm{S}$, et al. Constant replenishment from circulating monocytes maintains the macrophage pool in the intestine of adult mice. Nat Immunol. (2014) 15:929-37. doi: 10.1038/ni.2967

101. Bain CC, Scott CL, Uronen-Hansson H, Gudjonsson S, Jansson O, Grip $\mathrm{O}$, et al. Resident and pro-inflammatory macrophages in the colon represent alternative context-dependent fates of the same Ly6Chi monocyte precursors. Mucosal Immunol. (2013) 6:498-510. doi: 10.1038/mi.2012.89

102. Rivollier A, He J, Kole A, Valatas V, Kelsall BL. Inflammation switches the differentiation program of Ly6Chi monocytes from antiinflammatory macrophages to inflammatory dendritic cells in the colon. J Exp Med. (2012) 209:139-55. doi: 10.1084/jem.20101387

103. Tamoutounour S, Henri S, Lelouard H, de Bovis B, de Haar C, van der Woude $\mathrm{CJ}$, et al. CD64 distinguishes macrophages from dendritic cells in the gut and reveals the Th1-inducing role of mesenteric lymph node macrophages during colitis. Eur J Immunol. (2012) 42:3150-66. doi: 10.1002/eji.2012 42847

104. Kamada N, Hisamatsu T, Honda H, Kobayashi T, Chinen H, Kitazume MT, et al. Human $\mathrm{CD} 14+$ macrophages in intestinal lamina propria exhibit potent antigen-presenting ability. J Immunol. (2009) 183:1724-31. doi: 10.4049/jimmunol.0804369

105. Kamada N, Hisamatsu T, Okamoto S, Chinen H, Kobayashi T, Sato T, et al. Unique CD14 intestinal macrophages contribute to the pathogenesis of Crohn disease via IL-23/IFN-gamma axis. J Clin Invest. (2008) 118:2269-80. doi: $10.1172 / \mathrm{JCI} 34610$

106. Cassani B, Villablanca EJ, Quintana FJ, Love PE, Lacy-Hulbert A, Blaner WS, et al. Gut-tropic T cells that express integrin $\alpha 4 \beta 7$ and CCR9 are required for induction of oral immune tolerance in mice. Gastroenterology (2011) 141:2109-18. doi: 10.1053/j.gastro.2011.09.015

107. Hadis U, Wahl B, Schulz O, Hardtke-Wolenski M, Schippers A, Wagner N, et al. Intestinal tolerance requires gut homing and expansion of FoxP3+ regulatory $\mathrm{T}$ cells in the lamina propria. Immunity (2011) 34:237-46. doi: 10.1016/j.immuni.2011.01.016

108. Hepworth MR, Fung TC, Masur SH, Kelsen JR, McConnell FM, Dubrot $\mathrm{J}$, et al. Group 3 innate lymphoid cells mediate intestinal selection of commensal bacteria-specific CD4+ T cells. Science (2015) 348:1031-5. doi: $10.1126 /$ science.aaa4812

109. Laouar A, Haridas V, Vargas D, Zhinan X, Chaplin D, van Lier RAW, et al. CD70+ antigen-presenting cells control the proliferation and differentiation of $\mathrm{T}$ cells in the intestinal mucosa. Nat Immunol. (2005) 6:698-706. doi: $10.1038 /$ ni1212

110. Tyler CJ, McCarthy NE, Lindsay JO, Stagg AJ, Moser B, Eberl M. Antigen-presenting human gammadelta $\mathrm{T}$ cells promote intestinal CD4+ $\mathrm{T}$ cell expression of IL-22 and mucosal release of calprotectin. J Immunol. (2017) 198:3417-25. doi: 10.4049/jimmunol.17 00003

111. Drakesmith H, O'Neil D, Schneider SC, Binks M, Medd P, Sercarz E, et al. In vivo priming of $\mathrm{T}$ cells against cryptic determinants by dendritic cells exposed to interleukin 6 and native antigen. Proc Natl Acad Sci USA. (1998) 95:14903-8. doi: 10.1073/pnas.95.25.14903

112. Cooney R, Baker J, Brain O, Danis B, Pichulik T, Allan P, et al. NOD2 stimulation induces autophagy in dendritic cells influencing bacterial handling and antigen presentation. Nat Med. (2009) 16:90-7. doi: 10.1038/nm.2069

113. van Beelen AJ, Zelinkova Z, Taanman-Kueter EW, Muller FJ, Hommes DW, Zaat SA, et al. Stimulation of the intracellular bacterial sensor NOD2 programs dendritic cells to promote interleukin-17 production in human memory $\mathrm{T}$ cells. Immunity (2007) 27:660-9. doi: 10.1016/j.immuni.2007.08.013

114. Lee JC, Biasci D, Roberts R, Gearry RB, Mansfield JC, Ahmad T, et al. Genome-wide association study identifies distinct genetic contributions to prognosis and susceptibility in Crohn's disease. Nat Genet. (2017) 49:262-8. doi: $10.1038 /$ ng.3755
115. Abe K, Nguyen KP, Fine SD, Mo JH, Shen C, Shenouda S, et al. Conventional dendritic cells regulate the outcome of colonic inflammation independently of T cells. Proc Natl Acad Sci USA. (2007) 104:17022-7. doi: 10.1073/pnas.0708469104

116. Berndt BE, Zhang M, Chen GH, Huffnagle GB, Kao JY. The role of dendritic cells in the development of acute dextran sulfate sodium colitis. J Immunol. (2007) 179:6255-62. doi: 10.4049/jimmunol.179.9.6255

117. Ramalingam R, Larmonier $\mathrm{CB}$, Thurston RD, Midura-Kiela MT, Zheng SG, Ghishan FK, et al. Dendritic cell-specific disruption of TGF- $\beta$ receptor II leads to altered regulatory $\mathrm{T}$ cell phenotype and spontaneous multiorgan autoimmunity. J Immunol. (2012) 189:3878-93. doi: 10.4049/jimmunol.1201029

118. Uhlig HH, McKenzie BS, Hue S, Thompson C, Joyce-Shaikh B, Stepankova R, et al. Differential activity of IL-12 and IL-23 in mucosal and systemic innate immune pathology. Immunity (2006) 25:309-18. doi: 10.1016/j.immuni.2006.05.017

119. Hart AL, Al Hassi HO, Rigby RJ, Bell SJ, Emmanuel AV, Knight SC, et al. Characteristics of intestinal dendritic cells in inflammatory bowel diseases. Gastroenterology (2005) 129:50-65. doi: 10.1053/j.gastro.2005.05.013

120. Mann ER, Bernardo D, Ng SC, Rigby RJ, Al-Hassi HO, Landy J, et al. Human gut dendritic cells drive aberrant gut-specific t-cell responses in ulcerative colitis, characterized by increased IL-4 production and loss of IL-22 and IFNgamma. Inflamm Bowel Dis. (2014) 20:2299-307. doi: 10.1097/MIB.0000000000000223

121. Middel P, Raddatz D, Gunawan B, Haller F, Radzun HJ. Increased number of mature dendritic cells in Crohn's disease: evidence for a chemokine mediated retention mechanism. Gut (2006) 55:220-7. doi: 10.1136/gut.2004.063008

122. Ng SC, Benjamin JL, McCarthy NE, Hedin CR, Koutsoumpas A, Plamondon $S$, et al. Relationship between human intestinal dendritic cells, gut microbiota, and disease activity in Crohn's disease. Inflamm Bowel Dis. (2010) 17:2027-37. doi: 10.1002/ibd.21590

123. Di Sabatino A, Pickard KM, Gordon JN, Salvati V, Mazzarella G, Beattie RM, et al. Evidence for the role of interferon-alfa production by dendritic cells in the Th1 response in celiac disease. Gastroenterology (2007) 133:1175-87. doi: 10.1053/j.gastro.2007.08.018

124. Sakuraba A, Sato T, Kamada N, Kitazume M, Sugita A, Hibi T. Th1/Th17 immune response is induced by mesenteric lymph node dendritic cells in Crohn's disease. Gastroenterology (2009) 137:1736-45. doi: 10.1053/j.gastro.2009.07.049

125. Wu W, He C, Liu C, Cao AT, Xue X, Evans-Marin HL, et al. miR-10a inhibits dendritic cell activation and Th1/Th17 cell immune responses in IBD. Gut (2015) 64:1755-64. doi: 10.1136/gutjnl-2014-307980

126. Al-Hassi HO, Mann ER, Sanchez B, English NR, Peake ST, Landy J, et al. Altered human gut dendritic cell properties in ulcerative colitis are reversed by Lactobacillus plantarum extracellular encrypted peptide STp. Mol Nutr Food Res. (2014) 58:1132-43. doi: 10.1002/mnfr.201300596

127. Collins CB, Aherne CM, Kominsky D, McNamee EN, Lebsack MDP, Eltzschig $\mathrm{H}$, et al. Retinoic acid attenuates ileitis by restoring the balance between T-helper 17 and T regulatory cells. Gastroenterology (2011) 141:1821-31. doi: 10.1053/j.gastro.2011.05.049

128. Matsuno H, Kayama H, Nishimura J, Sekido Y, Osawa H, Barman S, et al. CD103+ Dendritic cell function is altered in the colons of patients with ulcerative colitis. Inflamm Bowel Dis. (2017) 23:1524-34. doi: 10.1097/MIB.0000000000001204

129. Laffont S, Siddiqui KR, Powrie F. Intestinal inflammation abrogates the tolerogenic properties of MLN CD103+ dendritic cells. Eur J Immunol. (2010) 40:1877-83. doi: 10.1002/eji.200939957

130. Brown CC, Noelle RJ. Seeing through the dark: new insights into the immune regulatory functions of vitamin A. Eur J Immunol. (2015) 45:1287-95. doi: 10.1002/eji.201344398

131. Erkelens MN, Mebius RE. Retinoic acid and immune homeostasis: a balancing act. Trends Immunol. (2017) 38:168-80. doi: 10.1016/j.it.2016.12.006

132. Hall JA, Cannons JL, Grainger JR, Dos Santos LM, Hand TW, Naik S, et al. Essential role for retinoic acid in the promotion of $\mathrm{CD} 4^{+} \mathrm{T}$ cell effector responses via retinoic acid receptor alpha. Immunity (2011) 34:435-47. doi: 10.1016/j.immuni.2011.03.003 
133. DePaolo RW, Abadie V, Tang F, Fehlner-Peach H, Hall JA, Wang W, et al. Coadjuvant effects of retinoic acid and IL-15 induce inflammatory immunity to dietary antigens. Nature (2011) 47:220-4. doi: 10.1038/nature09849

134. Magnusson MK, Brynjolfsson SF, Dige A, Uronen-Hansson H, Borjesson LG, Bengtsson JL, et al. Macrophage and dendritic cell subsets in IBD: ALDH+ cells are reduced in colon tissue of patients with ulcerative colitis regardless of inflammation. Mucosal Immunol. (2016) 9:171-82. doi: 10.1038/mi.2015.48

135. Takeuchi H, Yokota A, Ohoka Y, Iwata M. Cyp26b1 regulates retinoic acid-dependent signals in $\mathrm{T}$ cells and its expression is inhibited by transforming growth factor-beta. PLoS ONE (2011) 6:e16089. doi: 10.1371/journal.pone.0016089
Conflict of Interest Statement: The author declares that the research was conducted in the absence of any commercial or financial relationships that could be construed as a potential conflict of interest.

Copyright $\odot 2018$ Stagg. This is an open-access article distributed under the terms of the Creative Commons Attribution License (CC BY). The use, distribution or reproduction in other forums is permitted, provided the original author(s) and the copyright owner(s) are credited and that the original publication in this journal is cited, in accordance with accepted academic practice. No use, distribution or reproduction is permitted which does not comply with these terms. 